Оригинални научни рад

Zsuzsanna M. Juhász, Ph.D., Associate Professor

University of Szeged

Faculty of Law and Political Sciences

buntetojog@juris.u-szeged.hu

\title{
SITUATIONAL PICTURE ABOUT THE HUNGARIAN PRISON SYSTEM*
}

Abstract: The aim of this study is to illustrate somelor the main features of the Hungarian penitentiary system. Accordingly, the present paper attempts to introduce the main aspects of the institutions for the accommodation of inmates, as well as the most relevant information about the prisoners, prison conditions and the problems of the penitentiary system.

Keywords: prison system, prison population, overcrowding, punitive criminal law.

\section{INSTITUTIONS FOR THE ACCOMMODATION OF PRISONERS}

In Hungary the Prison Service as a law enforcement agency carries out custodial penalties and measures, coercive criminal procedure measures and also executes confinements as an administrative offence (detention for misdemeanour). The Hungarian Prison Service is subordinated to the Ministry of Interior. The Prison Service supervises and operates 30 prison establishments and limited companies established for the compulsory employment of inmates ${ }^{1}$. Currently 12 limited companies are operated by the Prison Service, these carry out mainly agricultural and light-industrial activities.

${ }^{*}$ This research was supported by the project Nr. EFOP-3.6.2-16-2017-00007, titled Aspects on the development of intelligent, sustainable and inclusive society: social, technological, innovation networks in employment and digital economy. The project has been supported by the European Union, co-financed by the European Social Fund and the budget of Hungary.

${ }^{1}$ The convicts are obliged to carry out the work assigned, thus denial of work is a serious misconduct. 
Besides prison establishments the Prison Service also includes institutions which are responsible for the training and recreation of the staff ${ }^{2}$ as well as health care of inmates ${ }^{3}$.

An important feature of the Hungarian prison system is that the penitentiary institutions are on the one part national and regional law enforcement institutes, and on the other part county law enforcement institutes. While the main task of national and regional law enforcement institutes is the execution of final and binding judgements (prisons for sentenced prisoners), county institutions carry out pre-trial detentions primarily. Currently, the tasks related to incarceration are performed by 15 national or regional law enforcement institutions and 15 county law enforcement institutions.

Within the prison system there are special institutions for females and juveniles.

Due to the fact that male convicts constitute the majority of the prison population and women make up only 7,7 percentage of the total national prison population ${ }^{4}$ there are only few prisons holding women. Female convicts can be placed in two women's prisons of the country, in Eger and Kalocsa (women-only prisons). Male prisoners can only be placed in women-only prisons in the interest of the operation of the institute, for example for institutional maintenance work. Moreover, in Hungary there is a combination of women's prisons and separate wings ${ }^{5}$ for women in men's prisons (male prisons with female wings), so female prisoners are also held in men's prisons, namely in Szombathely, Tiszalök, Pálhalma and Kiskunhalas National Penitentiary Institutions. Women can also be held in any of the county penitentiaries used for pre-trial prisoners.

There's only one place exist to accommodate mother and child together in the mother and baby unit in the country (with a capacity for 20 mothers and 21 children), which makes the contacts with relatives significantly more difficult. Female prisoner who gives birth in prison ${ }^{6}$ can keep her baby for the first 12 months, and a prisoner with a child under 12 months old can also apply for the opportunity to bring her child to prison with her. According to the Hungarian

\footnotetext{
${ }^{2}$ Namely the Education, Training and Rehabilitation Center of the Prison Service and the Faculty of Law Enforcement of the National University of Public Service.

${ }^{3}$ The Central Hospital of the Prison Service and the Forensic Psychiatric and Mental Institution.

${ }^{4} \mathrm{http}$ ://www.prisonstudies.org/country/hungary (Accessed on: 21.03.2020)

${ }^{5}$ According to the law female and male prisoners, similarly adult and juvenile inmates must be separated.

${ }^{6}$ According to the Decree of the Minister of Justice No. 8/2014 on access to healthcare to prisoners in detention facilities (art. 20.) pregnant prisoners should be transferred to the Central Hospital of the Prison Service upon discovering their pregnancies. After the medical check, either the prisoner is sent back to prison or her imprisonment is suspended. If the prison authority does not permit the suspension of the imprisonment, four weeks prior to the expected date of birth, the mother is transferred to the Central Hospital.
} 
Prison Code $^{7}$ inmate mothers should be held with their babies in the mother and baby unit for the first year of the child's life. Thus, for older children it means separation. ${ }^{8}$

Due to the small number of prisons for women, making the maintenance of family ties more difficult. The maintenance of family ties is especially problematic for juveniles, whose numbers are even smaller.

The largest number of juvenile inmates are placed in the oldest institution, which is located in Tököl, operating since 1963. There are also regional prisons for juveniles in Pécs (opened in 2006), Kecskemét (built in 1997), and Szirmabesenyő. The latter was originally not built for the detainment of young people; it was transformed in 2002 and became the second biggest institution keeping juveniles. There is only one penal institution for female juvenile offenders in Hungary. They are accommodated in Kecskemét regional prison (Bács-Kiskun County Prison).

According to the law, adult convicts can only be placed in a regional prison of juveniles in the interest of the operation of the institute.

Generally, less than $5 \%$ of the prison population are foreigners, ${ }^{9}$ which means that there is no specific institution for them, so they are kept together with the general prison population. Most foreign prisoners are nationals of/from the neighbouring countries. When it is possible, the prison authorities prefer to keep those foreign inmates together who speak the same language. Similarly, there is no specific institution for older prisoners, but they can accommodate in a special cellblock for senior detainees.

There are also specific institutions (currently numerically $3^{10}$ ) for the sick and the disabled. The Central Hospital of the Prison Service, which is located in Tököl, treats prisoners from prisons all over the country. According to the data of the Prison Service, ${ }^{11}$ on average the hospital treats 17,000 inmates. The Prison Service provides medical after-care for prisoners in the Chronic Aftercare Department of Unit III of the Szeged Strict and Medium Regime Prison (in Nagyfa). The Chronic Aftercare Department provides hospital care for in-patient detainees who suffer from chronic illnesses and who need rehabilitation. The third specific institution is the Forensic Psychiatric and Mental Institution, which was mainly established for compulsory psychiatric treatment of the prisoners (i.e. those who have committed violent crimes against other persons or crimes against public

\footnotetext{
${ }^{7}$ Act CCXL of 2013 on the Enforcement of Penalties, Measures, Certain Coercive Measures and Detention for Misdemeanour (hereinafter: Prison Code/Law Enforcement Code)

${ }^{8}$ According to the law children are allowed to visit their mothers once a month for $30 \mathrm{~min}$ utes in special visiting rooms.

${ }^{9} \mathrm{http} / / / \mathrm{www}$.prisonstudies.org/country/hungary (Accessed on: 21.03.2020)

${ }^{10}$ According to the information provided by the prison authorities a new and modern Law Enforcement Health Care Centre scheduled to be established in 2020 in Berettyóujfalu with 194 beds.

${ }^{11}$ https://bv.gov.hu/en/node/1929 (Accessed on: 22.03.2020)
} 
safety and there is a danger that they may commit similar crimes in the future, if they are not liable to punishment due to his/her mental disorder). The institution is located on the premises of Budapest Strict and Medium Regime Prison, but organizationally and territorially separated from the prison. These health care institutions are specialised in inpatient treatment, thus if no appropriate service is available within the system, the health care service is provided outside of the prison in a civil medical institute.

Two penitentiary institutions are worth mentioning that were built in the form of PPP schemes ${ }^{12}$ (based on the cooperation of the state and the private sector) in 2008, i.e. the Szombathely and Tiszalök National Penitentiary Institutions. According to the cooperation, the State supervises security operations and performs all detention-related regular and special tasks (i.e. the National Prison Service employs the guards of the prisons, as transportation, health care also under state control) and the contractor (a private company) is in charge of daily operations (provides services for example maintenance, operation, meal, washing and the employment of inmates at work).

An additional factor that most of the penitentiary institutions were built at the end of the 1800s and were designed primarily for the execution of pre-trial detentions with single cells. By way of example the first prison was built in 1842 in Balassagyarmat (town in northern Hungary) and it is still active today.

I would point out later that due to prison overcrowding, the majority of prisoners are held in collective cells ${ }^{13}$ (with occupancy 2-10 prisoners), single-occupancy accommodations are relatively rare (it's actually only in disciplinary, security and solitary confinement).

Due to the capacity expansion project the number of places to accommodate detainees has practically increased in the last years. While in 2014, the Hungarian prison system was capable of accommodating only 12,869 detainees in total, according to data concerning December $2019^{14}$ the official capacity of the detention institutions increased to 14.829 .

12 PPP=Public Private Partnership, i.e. cooperation between the public and private sectors. About the PPP project: Radnay József, “A PPP-projekt előkészítése, szervezeti háttere, a szerződés fö elemei,” Börtönügyi Szemle, 4/2007, 11-22.; Csere László, “A Tiszalökön PPP-konstrukcióban épülő bv. intézet megvalósításának előzményei,” Börtönügyi Szemle, 4/2007, 5-10.

${ }^{13}$ The number of people to be placed in a cell shall be defined in a way that each inmate has 6 cubic meters of air space and at least 4 square meters of living space in case of multi-occupancy accommodation/or at least 6 square meters of living space in case of single cell accommodation. When calculating the living space, the space covered by washbasin and toilet shall not be taken into account. Art. 121. of the new Rules of Law Enforcement [Ministry of Justice Decree No. 16/2014. (XII. 19.) on the detailed rules of execution of imprisonment, confinement, pre-trial detention and confinement replacing payment of disciplinary penalty]

${ }^{14} \mathrm{http}$ ://www.prisonstudies.org/country/hungary (Accessed on: 21.03.2020) 
In accordance with the principle of normalisation, prisoners shall be allocated, as far as possible, to-prisons close to their homes or places of social rehabilitation. Due to occupancy level of penal institutions in many cases inmates are not located near their homes. Since $1^{\text {st }}$ October 2008 the prison authorities apply the socalled occupancy-balancing programme to decrease overcrowding. The point of this programme is that the detainees are reallocated nationwide from crowded penitentiary institutions to less crowded ones. Beyond doubt, the method could result in more proportionate accommodation, however, at the same time it could entail the elimination of the family relations. As the CPT pointed out ,...the overcrowding "balancing" process is not an effective long-term response and generates immediately a number of serious problems for the prison management, staff and prisoners. The inmates spend a significant amount of time being transferred from one establishment to another, which leads to organisational difficulties. Moreover, prisoners were frequently held far away from their families and, as a result, suffered in practice from further restrictions on visits. This has led to tension between staff and inmates, as well as among prisoners themselves." 15

Within the prison system there are Special Regime Units for prisoners: for example the so-called HSR Unit for inmates serving long-term sentences, including whole/real life sentences $;{ }^{16} \mathrm{drug}$-free units for volunteering prisoners for preventive purposes and in order to improve the access of addicted prisoners to appropriate treatment; religious units for the maintenance and strengthening of the family and social ties of the prisoners and to promote religious practices; special units for prisoners who committed child sexual abuse. ${ }^{17}$

It also should be noted that within the penal institutions there are cellblocks used for solitary confinement of the prisoners. The solitary confinement is the most severe disciplinary sanction used in Hungary. These disciplinary measure can be applied to the prisoners for up to 25 days (in case of working inmates for up to 20 days). It may be imposed on an inmate who seriously violates prison

${ }^{15}$ [CPT/Inf (2014) 13]; § 39.

${ }^{16}$ Pursuant to the Prison Code (art. 105, para. 1,) only convicts sentenced to life imprisonment or to at least 15 years imprisonment whose specific treatment, disposition of their co-operation, their attitude to the order and safety of the institute, their individual security risk analysis justify may be placed in the HSR, for the purpose of gaining preparation for or reintegration into the community.

${ }^{17}$ The basic of the Unit is the provision of article 132 of the Prison Code: "If the convicted person has committed a criminal offence specified in Chapter XIX of the Penal Code against a person under eighteen years of age, or the sexual motive can be established from the circumstances in which the violent crime was committed against a victim under eighteen based on a risk assessment examination, then following the admission of the convicted person, the probability of the convict committing similar crimes after his or her release must be assessed. In case of potential recidivism, participation (on a voluntary basis) in psychotherapy or other trainings reducing the likelihood of repeated infringement must be offered to the convict." 
orders. During solitary confinement the prison authority may apply restrictions: for example, the prisoner is deprived of the possibility to contact his/her visitors, take part in cultural and sport activities; participate with other prisoners in religious events, receive and send parcels and letters, make phone calls.

In Hungary there are three subtypes of national penitentiary institutions: maximum-security penitentiaries - strict regime prisons (the Hungarian name fegyház), medium-security penitentiaries - medium regime prisons (the Hungarian name börtön) and low-security penitentiaries - light regime prisons (the Hungarian name fogház). ${ }^{18}$ These are the three different basic enforcement degrees of the severity of imprisonment in the Hungarian penal system. According to the Penal Code,${ }^{19}$ if the court imposes a sentence of imprisonment, it shall be enforced in low-security, medium-security or high-security penal institution. For example, in case of life imprisonment a sentence shall be served in a high-security penal institution, or imprisonment imposed for a misdemeanour shall be enforced in a low-security penal institution, unless the convict is a recidivis $\mathrm{t}^{20}$. In line with the relevant criteria of the Penal Code, the enforcement degrees of the imprisonment are determined by the sentencing court. ${ }^{21} \mathrm{An}$ important factor is, that with regard to the circumstances, which are taken into account at sentencing, the penalty may be ordered to be enforced in a penal institution one level below or above the security level specified in the Penal Code.

The types among others differ by the degree of the severity of detention and supervision; segregation from the outside world; movement within the premises of the prison; life regime, amount of money allotted for personal needs; rewards and disciplinary sanctions, participation in the prison activities, reintegration's programs. The strictest rules are applied in high-security penal institutions and the most lenient rules in low-security prisons. For example, in high-security prisons the prisoners may move within the parameters of the prison only under supervision, in medium-security prisons they may move freely in determined areas

18 There are only medium and low-security prisons for juveniles. According to the Penal Code imprisonment shall be enforced in a medium-security penal institution for juveniles if

a) the juvenile is sentenced to imprisonment for two years or more for committing a felony,

b) the juvenile sentenced to imprisonment for one year or more is a recidivist, or

c) within three years prior to committing the intentional criminal offence, the juvenile sentenced to imprisonment for one year or more was sentenced to special education in a reformatory for committing an intentional criminal offence. Apart from the cases specified in paragraph (1) of 110 Section, imprisonment shall be enforced in a low-security penal institution for juveniles.

${ }^{19}$ Act C of 2012 on the Penal Code (hereinafter: Penal Code), art. 35, para. 1.

${ }^{20}$ In legal terminology the perpetrator of an intentional criminal offence shall be considered a recidivist if he/she has already been sentenced to immediate imprisonment for committing an intentional criminal offence, and the period between his/her sentence being served or its enforceability being terminated and the perpetration of the new criminal offence is shorter than 3 years.

${ }^{21}$ The different enforcement degrees of the imprisonment are determined by the court, but the concrete penal institution appointed by the law or by a measure of the national commander. 
within the parameters of the institute and in low-security penal institutions inmates may move freely within the parameters of the prison.

Because of the number and composition of the detainees, the character of the criminal offences committed by them, and thus the length of the sentences, as well as the occupancy of the institutions, placing detainees in open penitentiary institutions (=in low-security prisons) is rarely enforceable in Hungary. The ratio of detainees who serve their sentences in high-security penitentiaries is high, and also a significant ratio of the detainees within those serving their sentences in medium-security prisons can be placed only in closed penitentiary institutions (=in high or medium-security prisons).

One provision promoting the individualization of punishments stipulates that the differentiated execution of imprisonment is realized by using different enforcement degrees that are different in terms of several aspects. Another important law enforcement instrument and educational tool is the so-called change of the enforcement degree. Upon the decision of the penitentiary judge (judge responsible for enforcement) ${ }^{22}$ of overseeing the conditions and enforcement degrees of the severity of imprisonment the convict is sentenced to may be prescribed one degree up or down. The educational character of the enforcement degree change is manifested in the possibility of being placed under a more lenient or stricter regime and it may motivate convicts to show appropriate behaviour during their detention.

According to the enforcement degrees of the imprisonment the majority of the prisoners held in medium-security prison (54\%), 36\% of the convicts belonged to the strictest category (high-security prison) and the number of those under low-security regime represented the smallest proportion in $2018^{23}$ as illustrated by the pie chart below.

\section{enforcement degrees of the imprisonment}

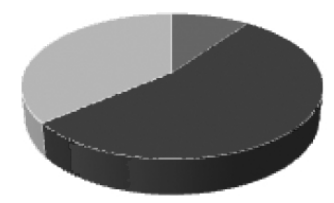

- low-security prison

- medium-security prison

- high-security prison

${ }^{22}$ In Hungary the judge responsible for penal execution is an independent judicial authority. Its main function is to refine the further legal framework of the imposed sanction and to alter or to revise it, if it is necessary. The penal execution judge will decide among others about the release on parole from fixed-term and life imprisonment.

${ }^{23}$ Hungarian Prison Service, The Yearbook of Hungarian Prison Service 2018, 12. 
Inside the all three different basic enforcement degrees the Hungarian regulation make distinguish between stricter, general and milder regimes. The classification of the prisoners in stricter, general or milder regimes based on an individual risk assessment, in accordance with the principle of individualisation. In each regime there are different arrangements inter alia for the frequency and the duration of the contact with the outside world, the amount that may be used for the personal needs of the convict, the personal items permitted to hold, the locking of his/her cell door, work outside the prison facility. To take an actual example, in a maximum-security prison in strict regime a prisoner may receive a visitor once a month for 60 minutes, in a the same penitentiary institution, but in general regime may receive a visitor once a month for 90 minutes, while in a more lenient regime he/ she may receive a visitor twice a month, each time for 60 minutes. Therefore, this so-called regime-system plays an important motivating role in the life conditions within the prison and the reintegration of the prisoners.

\section{FACTS ABOUT THE PRISON POPULATION}

First of all, it's important to emphasize, that prisoner in Hungary is a collective term used for individuals subjected to deprivation of liberty and held in various penitentiary facilities. This category includes inmates serving imprisonment as a final court order, as well as pre-trial detainees, individuals subjected to compulsory psychiatric treatment (mentally disordered offenders who cannot be punished because of insanity) and offenders serving confinement as a penalty (penalty imposed for minor offences in the duration of 5-90 days/for juveniles 3-30 days).

According to the official statistics, as the following chart shows, in 2018 80\% of the total prison population was convicted, $17 \%$ pre-trial detainee, $2 \%$ under confinement as a penalty, and $1 \%$ mentally disordered perpetrator under compulsory psychiatric treatment.

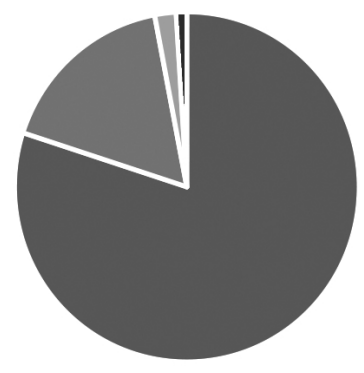

- convicted - pre-trial d. = confinement as a penalty - compulsory p. treatment Source: The Yearbook of Hungarian Prison Service 2018, p. 12. 
As in many others countries, the female prisoners continue to constitute a small proportion of the general prison population in Hungary: expressed as a percentage in 2019 the female prisoners made up 7,7 \% of the total prison population. ${ }^{24}$

In Hungary, as a general rule, the minimal age of criminal responsibility is 14, thus a person shall not be liable to punishment if he/she has not attained this age when committing the punishable act. There are, however, exceptions to this rule: thus, children above 12 and under 14 can be charged for homicide, voluntary manslaughter, bodily harm, terrorist act, robbery and plunder, if the child can judge, recognise the consequences of his/her criminal actions at the time of commission. It is important to underline that children under 14 cannot be sent to penitentiaries, they shall only be subject to measures and their special education in juvenile reformatories ${ }^{25}$ can be ordered. According to the law, those who have not attained the age of 18 years when committing the criminal offence shall qualify as juveniles, but who have committed a crime as juveniles may continue to serve their sentence in a juvenile prison until the age of 21 and are regarded as juveniles for the purpose of serving the sentence. Life imprisonment is explicitly prohibited for persons aged under 20 at the time they committed the criminal offence.

We welcome the fact that the juvenile prison population has dropped significantly over the past years, at least partially to the increased use of non-custodial sanctions and mediation (particularly in property-related crimes). It can be stated that juveniles represent low rate of the total prison population: on 31 December 2019 1,1 \% of convicted or remand juvenile prisoners were in custody. ${ }^{26}$ The same comments can made about the foreign inmates: in the same year $4,9 \%$ of the total prison population was foreign. ${ }^{27}$

Similarly, to the previous year's data, the majority of the prisoners belonging to the 30-39 years age group. It also can be stated that elder prisoners (the age group over 60 years) represented low rate of the total prison population $(3,98 \%$ of all inmates) in 2018, but the ratio of senior detainees in the entire prison population has been continuously increasing during the last years, as illustrated by the table 1 below.

${ }^{24}$ https://www.prisonstudies.org/country/hungary (Accessed on: 21.03.2020)

${ }^{25}$ In Hungary a special measure can be applied against juvenile perpetrators, namely the special education in a reformatory institution, which is a sanction involving deprivation of liberty. According to the Penal Code (art. 120, para. 1) special education in a reformatory may be ordered by a court if placement in a reformatory is necessary for a juvenile to be raised successfully. A person may be a subject to special education in a reformatory if he/she has attained the age of 12 at the time of commission, but the measure cannot be applied against perpetrators who turned 20 at the time of sentencing. The shortest period of special education in a reformatory is 1 year, at the same time the general maximum is 4 years. There are 5 reformatories across Hungary, they are part of the child protection system.

${ }^{26} \mathrm{https}: / /$ www.prisonstudies.org/country/hungary (Accessed on: 21.03.2020)

${ }^{27}$ Hungarian Prison Service, The Yearbook of Hungarian Prison Service 2018, 13. 


\begin{tabular}{|l|c|c|c|c|c|c|c|c|}
\hline & $\mathbf{2 0 1 1}$ & $\mathbf{2 0 1 2}$ & $\mathbf{2 0 1 3}$ & $\mathbf{2 0 1 4}$ & $\mathbf{2 0 1 5}$ & $\mathbf{2 0 1 6}$ & $\mathbf{2 0 1 7}$ & $\mathbf{2 0 1 8}$ \\
\hline $\begin{array}{l}\text { elder prisoners } \\
\text { percentage of } \\
\text { prison population }\end{array}$ & $1,83 \%$ & $2,14 \%$ & $2,13 \%$ & $2,66 \%$ & $2,8 \%$ & $3,0 \%$ & $3,8 \%$ & $3,98 \%$ \\
\hline
\end{tabular}

Table 1. Source: Hungarian Prison Service: Review of Hungarian Prison Statistics 2019 vol. 1. p. 6.

The aging of the prison population is one of the possible effects of the increased application of life imprisonment without parole, life imprisonment and other imprisonment sentences of long duration, the stricter punishments, the rules and practice of parole. In addition to the general aging of the society, these elements of the punitive criminal policy can significantly influence the number of detainees who spend their later lives as inmates of penitentiary institutions.

Although currently the number of detainees over 60 years of age is still insignificant compared to the entire prison population, the detention of senior detainees already challenging the prison system with special tasks. In this regard, primarily health issues enjoy priority, but institutions are often poorly suited for intensive care of older prisoners. Detention facilities try to place senior detainees in cells with fewer inmates if possible, specifically on lower bunks. In addition, they pay attention to placing detainees of similar age together. ${ }^{28}$

In respect of re-offending more than half of the inmates are first time offenders, $6 \%$ are repeat offender not classified as recidivist, while recidivists represent approximately $42 \%$ of the prison population, of whom are $8,58 \%$ are recidivist, $18,33 \%$ are multiple recidivis $\mathrm{t}^{29}, 12,4 \%$ are special recidivist ${ }^{30}$ and $2,71 \%$ are violent multiple recidivist ${ }^{31}$.

When reviewing the development of the prison population, it stands out that the number of detainees was continuously increasing between 2008 and 2016: the average detainee number of 14,782 detainees registered in 2008 has increased every year ( 2009 - 15,373 detainees; 2010 - 16,203 detainees; 2011 - 17,195 detainees; 2012 - 17,515 detainees; 2013 - 18,146 detainees), and in 2014 this figure had already exceeded $18,000(18,204),{ }^{32}$ while $13^{\text {th }}$ October 2015 data showed

${ }^{28}$ Juhász Zsuzsanna, „Az elöregedő börtönnépesség problémái,” Börtönügyi Szemle 2/2012, 13.

${ }^{29}$ According to the Penal Code (art. 459, para, 1, it. 31.) a person shall be considered a multiple recidivist, if he/she has already been sentenced to immediate imprisonment as a recidivist prior to committing the intentional criminal offence, and the period between his last sentence being served or its enforceability being terminated and the perpetration of the new criminal offence punishable by imprisonment is shorter than three years.

${ }^{30}$ A recidivist shall be considered a special recidivist if he committed the same criminal offence or similar criminal offences both times.

${ }^{31}$ A multiple recidivist shall be considered a violent multiple recidivist if he committed a violent criminal offence against a person all three times.

${ }^{32}$ Hungarian Prison Service, Review of Hungarian Prison Statistics 1/2015, 5. 
18,424 detainees. The number of prisoners decreased to 17,658 in $2016,17,343$ in 2017 and 16,303 in 2018 and 16,334 on 31 December 2019, so during the previous years the number of prisoners was characterized by a decrease and a stagnation.

\section{Re-offending}

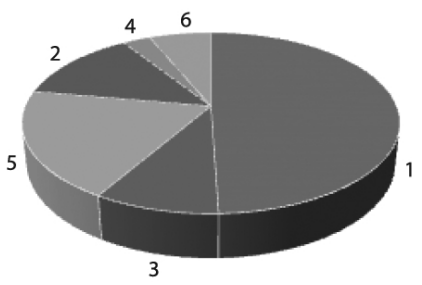
1/ frst time offender
3 " recidivist
5 = multiple recidivist
2- special recidivist
4 " violent multiple recidivist
6 - repeat offender not recidivist

Source: Hungarian Prison Service: Review of Hungarian Prison Statistics 2019 vol. 1. p. 11.

Due to the reduction in the number of prisoners, the prison population rate (number of prisoners per 100,000 people) also decreased in the last years: it was 180 in 2016, and 173 in 2018. It has to be noted that despite the decrease of the prison population rate, we still have particularly high incarceration rate: in terms of this indicator Hungary may be classified among the countries with exceptionally high rates, since the number of detainees per 100,000 citizens is over $150 .{ }^{33}$ It's important to emphasise that a high incarceration indicator, i.e. the number of detainees per 100,000 citizens, indicates overcrowding in the majority of the countries, which is the case in Hungary. ${ }^{34}$

Table 2 below shows the abovementioned data.

\begin{tabular}{|c|c|c|}
\hline Year & average number of prisoners & prison population rate \\
\hline 2008 & 14.782 & 147 \\
\hline 2009 & 15.373 & 164 \\
\hline 2010 & 16.203 & 163 \\
\hline 2011 & 17.195 & 174 \\
\hline
\end{tabular}

${ }^{33}$ According to the Council of Europe Annual Penal Statistics for 2018 the European median was 102,5! Aebi, Marcelo F., Tiago, Melanie M., "SPACE I (2018) - Council of Europe Annual Penal Statistics: Prison populations," Strasbourg, Council of Europe, 2.

The SPACE I 2018 survey contains information from 44 out of 52 prison administrations in the 47 Council of Europe member states. Hungary remains among the Member States which have not replied to the survey.

${ }^{34}$ United Nations Office on Drugs and Crime, "Handbook on strategies to reduce overcrowding in prisons," Criminal Justice Handbook Series, New York, 2013, 9. 


\begin{tabular}{|c|c|c|}
\hline 2012 & 17.515 & 173 \\
\hline 2013 & 18.146 & 184 \\
\hline 2014 & 18.204 & 182 \\
\hline 2015 & 18.424 & 180,8 \\
\hline 2016 & 17.658 & 180 \\
\hline 2017 & 17.343 & 173 \\
\hline 2018 & 16.303 & 167 \\
\hline 2019 & 16.334 & 167 \\
\hline
\end{tabular}

Table 2. Source: http://www.prisonstudies.org/country/hungary and Review of Hungarian Prison Statistics

In view of the sentences imposed during the last years, it can be established that a sharp increase may be observed in respect of long-term imprisonments, regarding both 5 to 10 -year, and more than 10 -year imprisonment sentences. While in 2010 631, in 2011 707, in 2012 702, in 2013757 and in 2014824 detainees were serving their more than 10-year imprisonment sentences, in 2018 this number climbed to 1676 ! The number of to 10 -year imprisonment sentences showed a similar trend, as illustrated by the table 3 below.

\begin{tabular}{|l|c|c|c|c|c|c|}
\hline & $\mathbf{2 0 1 0}$ & $\mathbf{2 0 1 1}$ & $\mathbf{2 0 1 2}$ & $\mathbf{2 0 1 3}$ & $\mathbf{2 0 1 4}$ & $\mathbf{2 0 1 8}$ \\
\hline 5 to 10-years & 631 & 707 & 702 & 757 & 824 & 1676 \\
\hline more than 10 years & 1753 & 1985 & 2279 & 2522 & 2674 & 3440 \\
\hline
\end{tabular}

Table 3. Source: Hungarian Prison Service: Review of Hungarian Prison Statistics 2019 vol. 1. p. 11.

At the end of 2018 there were 57 prisoners $(0,43 \%$ of the total prison population) sentenced to real/actual life imprisonment as the most severe legal consequence of the Hungarian regulation. The term "real/actual life imprisonment" means that the court does not see any possibility of parole, or the exclusion of parole is stipulated by law, ${ }^{35}$ thus imprisonment may actually last until the end of the offender's life. It is also important to note that the number of convicts sentenced to life imprisonment without parole has been increasing year by year (in 201346 persons were completing their life imprisonment without parole). ${ }^{36}$

The strictness of law shown towards convicts sentenced to life imprisonment without parole represented in several regards in the provisions of the Penal Code and Law Enforcement Code. Thus, for example, for important reason - in par-

35 The court may exclude (art. 44, para. 1 of the Penal Code) or shall exclude (art. 44, para. 2) conditional release if the court finds that it is necessary to isolate the convict from society permanently.

${ }^{36}$ Hungarian Prison Service, Review of Hungarian Prison Statistics 1/2019. 11. 
ticular the personal or family circumstances, health condition of the convict - the Hungarian regulation provides opportunity to interrupt the execution of imprisonment ex officio or upon request. However, this legal instrument shall not be applied in case of those defendants sentenced to life imprisonment without parole. ${ }^{37}$ The so-called change of the enforcement degree also shall not apply to convicts sentenced real life imprisonment.

In respect of life imprisonment without parole several legal academics have voiced their concerns, referring among others to the inhumane, cruel character of this type of punishment, and that it opposes the principle of human dignity. The Hungarian regulation was brought before the European Court of Human Rights (hereinafter: ECtHR) after László Magyar, who had been sentenced to life imprisonment without parole, referred to the Strasbourg Court. In László Magyar's case against Hungary ${ }^{38}$ the ECtHR found the Hungarian regulation to be in violation of the Convention because it failed to provide any possibility of parole even in principle for the convict sentenced to life imprisonment excluded from the possibility of parole. In its decision the ECtHR indicated that the pardon that may be granted by the head of state (President of the Republic) cannot be considered as a review procedure acceptable by the Convention, as it cannot be established what factors the President of the Republic takes into consideration in course of his decision. For this reason, the Strasbourg Court found that a review system shall be introduced, which unambiguously establishes when and under which conditions the convict may be released.

Resulting from the ECtHR judgement the mandatory procedure of clemency for convicts sentenced to life imprisonment and excluded for the possibility of parole was added to the Prison Code. It shall be noted here that in principle this mandatory procedure does not prevent the convict sentenced to life imprisonment without parole to submit a request for pardon to the President of the Republic as well. Therefore, currently it is mandatory to conduct a procedure of clemency in case of convicts sentenced to real life imprisonment. However, it is important to note that the mandatory procedure of clemency simultaneously does not constitute obligation to release such convicts. However, on the other hand, if the clemency decision is negative, then 2 years later another mandatory procedure of clemency shall be started..$^{39}$

The mandatory procedure of clemency may be started on condition that the convict grants his consent. Therefore, if the convict does not grant his consent, or he refuses to make a statement, then the procedure cannot be conducted. Another significant condition of starting the mandatory procedure of clemency is that 40 years of the imprisonment punishment shall elapse. Due to the wording of the act,

\footnotetext{
${ }^{37}$ Art. 116, para. 3 of the Prison Code

${ }^{38}$ Application no. 73593/10, judgment of 20 May 2014

${ }^{39}$ Art. $46 / \mathrm{H}$ of the Law Enforcement Code
} 
the time spent in pre-trial detention shall be disregarded in the calculation of the 40 years. ${ }^{40}$ Thus, this provision also means that convicts sentenced to life imprisonment without parole have to spend at least 40 years in penitentiary institutions. ${ }^{41}$

\section{THE MAIN PROBLEM DRIVER OF THE PRISON SYSTEM}

Due to the decrease of the number of prisoners and the increase in the capacity of prisons the overcrowding rate/occupancy rate represents a decrease in Hungary: the average occupancy rate was $143 \%$ ! in $2014,129 \%$ in $2017,113 \%$ in $2018^{42}$ and $110 \%$ in $2019 .{ }^{43}$ On the one hand, it's important to note that the latter indicators shows the average occupancy of Hungarian institutions, meanwhile there were institutions where overcrowding exceeded $110-113 \%$. In order to gain a clearer and more complete picture of the situation, I have to mention the importance of the Szombathely and Tiszalök National Penitentiary Institutions, that were built in PPP cooperation. These two institutions have important roles in the temporary decrease of overcrowding, considering that if the state wanted to accommodate more detainees than the official capacity, then - according to the agreement between the Hungarian State and the investors - the state has to pay a great amount for this. For example, the operating contract for the Tiszalök Institute, which is able to accommodate 700 detainees, allows a $+/-10 \%$ deviation from this number, however, the number of detainees shall be maintained around 760-770 detainees and the occupancy of the institution shall not exceed $110 \% .{ }^{44}$

On the other hand, the average occupancy rate of prisons was always above 100 per cent in Hungary. So, overcrowding of prisons is a long-term, acute problem and the current state of Hungarian prisons could be best characterised by the huge number of detainee population, as well as by one of the potential consequences of large prison population, namely the overcrowding of penitentiary institutions.

Given the abovementioned negative indicators it is not surprising that in its decision published in $10^{\text {th }}$ March 2015 (Varga and others vs. Hungary) ${ }^{45}$ the Strasbourg

${ }^{40}$ Art. 46/B, para.1 of the Law Enforcement Code, i.e. 40 years shall elapse of the imprisonment punishment.

${ }^{41}$ In the case of T. P. and A. T. v. Hungary (Applications nos. 37871/14 and 73986/14) the Court found that, in view of the lengthy period the prisoners were required to wait before the commencement of the "mandatory clemency procedure" (i.e. 40 years), coupled with the lack of sufficient procedural safeguards, the prisoners' life sentences could not be regarded as de facto reducible as required under Article 3 of the Convention.

${ }^{42}$ Hungarian Prison Service, Review of Hungarian Prison Statistics 1/2019. 9.

${ }^{43} \mathrm{https}$ ://www.prisonstudies.org/country/hungary (Accessed on: 21.03.2020)

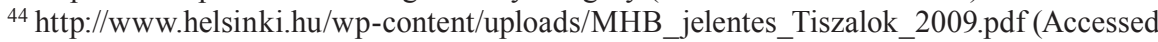
on: 11.03 .2020 )

${ }^{45}$ Application nos. 14097/12, 45135/12, 73712/12, 34001/13, 44055/13, and 64586/13, judgment of 10 March 2015 
Court ordered Hungary to eliminate the structural problems in its law enforcement system. The case-law of the ECtHR exemplifies that detainees in Hungary are often placed in overcrowded penitentiary institutions, which does not comply with the requirement of dignified, healthy detention conditions. Considering that around that time there were approximately 450 request before the ECtHR that were filed from Hungary and objected to the conditions of detention, the Strasbourg panel concluded that due to overcrowding, violations of rights occur in the country on a systemic level.

The Court reiterates that the inadequate conditions of detention originated in a widespread problem within the Hungarian prison system, justifying a pilot-judgment procedure of the recurrent and persistent nature of the problem identified. According to the judgment the solution would be the reduction of the number of prisoners by more frequent use of non-custodial measures and minimizing the use of pre-trial detention. The Court pointed to the recommendations of the Committee of Ministers to encourage prosecutors and judges to use alternatives to detention and redirect their criminal policy towards the reduced use of detention.

It is important to point out that the principal government objective is the construction of new penitentiary institutions, and the reactivation of institutions that had been closed earlier, i.e. increasing the number of places. The program for increasing the number of places has been started since 2010. In the framework of this among others the new prison quarter was opened is the Budapest Penitentiary and Prison, where 41 cells were built during the investment and partly through work performed by detainees. Similarly, the facility in Martonvásár was put into operation again after being closed down due to financial reasons. The last time in 2019 the construction process continued with the new building in Kiskunhalas, which has capacity to hold 470 male and female prisoners.

In July 2016 the Government made an updated action plan to resolve the overcrowded nature of its prisons and introduced a complaint and compensation remedy system for the grievances caused by the placement conditions violating fundamental rights. The amount of compensation was fixed at 1200-1600 Forints per day. In case of Domján v. Hungary (application no. 5433/17) the Strasbourg Court found that the compensation remedy system is able to guarantee redress, as a result, in November 2016, suspended the applications pending before it concerning poor conditions of detention in Hungary. More recently however the Government has suspended the payments of compensations to prisoners for overcrowded prison conditions until June 15, 2020.46

To summarise the present situation, overcrowding and inadequate prison conditions remain a huge problem in Hungary. The fight against the overcrowding

\footnotetext{
${ }^{46}$ Resolution 1004/2020. (I. 21.) of the Government on the immediate action against abusing the compensation procedures launched due to prison overcrowding
} 
of prisons presumes a comprehensive strategy, as the first step of which the reasons leading to overcrowding shall be analysed. Because in Hungary the key factor contributing to prison overcrowding is the punitive criminal law, inter alia we have to review and revision of our criminal justice legislation and practice. So until then the capacity-building projects not accompanied by comprehensive legal reform the extensive prison construction will also increase the prison population and won't offer a real solution to the systematic problem of overcrowding. Taking into account that the increased use of imprisonment and increased length of imprisonment are important factors leading to overcrowding, the early release schemes like parole or reintegration custody ${ }^{47}$ are very important in connection with solving the problem. Nevertheless, it should be added that these legal institutions are alone cannot reduce the rates of imprisonment as the existing measures and legal actions are not capable of rectifying the violations of inhuman conditions of detention.

\section{REFERENCES}

Books and articles

Aebi, Marcelo F., Tiago, Melanie M., "SPACE I (2018) - Council of Europe Annual Penal Statistics: Prison populations," Strasbourg, Council of Europe, 2.

Csere László, "A Tiszalökön PPP-konstrukcióban épülő bv. intézet megvalósításának előzményei," Börtönügyi Szemle, 4/2007, 5-10.

Hungarian Prison Service, The Yearbook of Hungarian Prison Service 2018, 12.

Hungarian Prison Service, Review of Hungarian Prison Statistics 1/2015, 5.

Hungarian Prison Service, Review of Hungarian Prison Statistics 1/2019

Juhász Zsuzsanna, „Az elöregedő börtönnépesség problémái,” Börtönügyi Szemle, 2/2012, 13.

Radnay József, "A PPP-projekt előkészítése, szervezeti háttere, a szerződés fő elemei," Börtönügyi Szemle, 4/2007, 11-22.

United Nations Office on Drugs and Crime, "Handbook on strategies to reduce overcrowding in prisons," Criminal Justice Handbook Series, New York, 2013, 9.

Legislative acts

Act $\mathrm{C}$ of 2012 on the Penal Code

Act CCXL of 2013 on the Enforcement of Penalties, Measures, Certain Coercive Measures and Detention for Misdemeanour (Prison Code/Law Enforcement Code)

CPT/Inf (2014) 13; § 39.

47 The main point of the reintegration custody that the convict who satisfied the statutory conditions may spend the last 10 months or in case of negligent criminal offence 1 year of his/her penalty outside the prison in a designated home. 
Decree of the Minister of Justice No. 8/2014 on access to healthcare to prisoners in detention facilities

Ministry of Justice Decree No. 16/2014. (XII. 19.) on the detailed rules of execution of imprisonment, confinement, pre-trial detention and confinement replacing payment of disciplinary penalty

\section{Website references}

World Prison Brief, Hungary, http://www.prisonstudies.org/country/hungary

Website of the Hungarian Prison Service, https://bv.gov.hu/en/node/1929

Website of the Hungarian Helsinki Committee, http://www.helsinki.hu/wp-content/ uploads/MHB_jelentes_Tiszalok_2009.pdf 
Др Жужана М. Јухас, ванреяни йрофесор

Универзитетей у Сеіееину

Правни факулитети

buntetojog@juris.u-szeged.hu

\section{Приказ садашњег стања затворског система у Мађарској}

Сажетйак: Циљ ове ст̄иуяје је йриказ неколико йлавних/значајних карак-

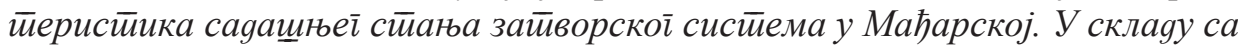

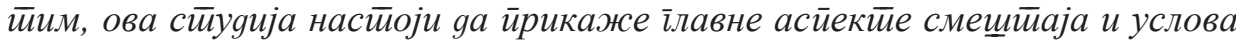
држања зайвореника у казнено-йоиравним инстииичцијама, о оносно настиоји gа иррикаже најважније информаиије у вези осуђеника, зативорских услова и ироблема који се јављају у вези зайворской сисиемм.

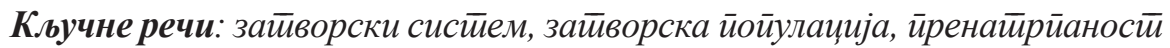
зайвора, йуниииивно казнено ирравосуђе.

Датум пријема рада: 27.04.2020. 